Cahiers $d u$ MONDE RUSSE

\section{Cahiers du monde russe}

Russie - Empire russe - Union soviétique et États indépendants

48/2-3 | 2007

Les résonances de 1905

\title{
«Pabočij vopros» i itogi 1905 goda
}

\section{Timur Ja. VALETOV}

\section{OpenEdition \\ Journals}

Édition électronique

URL : https://journals.openedition.org/monderusse/9001

DOI : 10.4000/monderusse. 9001

ISSN : $1777-5388$

Éditeur

Éditions de l'EHESS

Édition imprimée

Date de publication : 15 avril 2007

Pagination : 259-274

ISBN : 978-2-7132-2147-7

ISSN : $1252-6576$

\section{Référence électronique}

Timur Ja. VALETOV, « «Pabočij vopros» i itogi 1905 goda », Cahiers du monde russe [En ligne], 48/2-3 | 2007, mis en ligne le 01 janvier 2007, consulté le 04 septembre 2022. URL : http://

journals.openedition.org/monderusse/9001 ; DOI : https://doi.org/10.4000/monderusse. 9001 


\title{
CAIR N
}

chercher : repérer : avancer

Cet article est disponible en ligne à l'adresse :

http://www.cairn.info/article.php?ID REVUE=CMR\&ID NUMPUBLIE=CMR 482\&ID ARTICLE=CMR 4820259

\section{«Paboč ij vopros» i itogi 1905 goda}

\author{
par Timur JA. VALETOV
}

| Editions de l'EHESS | Cahiers du monde russe

2007/2-3 - Vol 48

ISSN 1252-6576 | ISBN 9782713221477 | pages 259 à 274

Pour citer cet article :

- Ja. VALETOV T., «Pabocij vopros» i itogi 1905 goda, Cahiers du monde russe 2007/2-3, Vol 48, p. 259-274.

Distribution électronique Cairn pour les Editions de l'EHESS.

(C) Editions de l'EHESS. Tous droits réservés pour tous pays.

La reproduction ou représentation de cet article, notamment par photocopie, n'est autorisée que dans les limites des conditions générales d'utilisation du site ou, le cas échéant, des conditions générales de la licence souscrite par votre établissement. Toute autre reproduction ou représentation, en tout ou partie, sous quelque forme et de quelque manière que ce soit, est interdite sauf accord préalable et écrit de l'éditeur, en dehors des cas prévus par la législation en vigueur en France. Il est précisé que son stockage dans une base de données est également interdit. 
ТИМУР Я. ВАЛЕТОВ

\section{«РАБОЧИЙ ВОПРОС » И ИТОГИ 1905 ГОДА}

Революция 1905-1907 годов, столетие которой отметилось недавно, - это историческое явление большого масштаба. Фактически, вся Российская империя в той или иной степени оказалась вовлечена в водоворот событий: многочисленные крестьянские бунты, волнения матросов и солдат, студенческие выступления, появление и активная деятельность либеральных партий. Потрясения затронули всех. Однако чаще всего первая русская революция ассоциируется с невиданным до того всплеском рабочего движения, и это неслучайно. Дело не только и не столько в том, что именно рабочие строили баррикады на Красной Пресне; главное - это их стачечная борьба, охватившая буквально всю страну. В литературе многократно отмечен резкий рост числа забастовок в 1905-1907 гг. по сравнению с предыдущими годами; менее известно, но тоже весьма интересно, что в 1905-1907 гг. заметно увеличилось по сравнению с предыдущими годами и число жалоб рабочих на предпринимателей, поданных в фабричную инспекцию, притом резко выросло число коллективных требований и, соответственно, число подавших жалобы (см. рис. 1). Таким образом, в это время резко возросли численные показатели обоих доступных рабочим видов протеста. И хотя правительству удалось в итоге подавить революцию, советские историки были едины в том, что рабочие выступления дали ощутимые экономические результаты. В данной статье ставится задача проследить, как и в чем изменилось положение рабочих - с точки зрения самих рабочих, предпринимателей и правительства.

Нельзя не отметить, что проблема развития взаимоотношений промышленных рабочих с хозяевами и администрацией предприятий сама по себе далеко не нова, она часто обсуждалась в исследовательской литературе, в том числе и в связи с потрясениями 1905-1907 гг. Историография первой русской революции воистину огромна. Вполне естественно, что уже во время и сразу 
после происшедших событий некоторые наблюдатели принялись давать свою, часто публицистическую, их оценку; более того, уже в 1906 г. был издан первый сборник материалов к их истории ${ }^{1}$. Позднее исследовательские работы по истории революции 1905-1907 гг., а также сборники документов и материалов, издавались постоянно; в СССР многочисленными публикациями на эту тему были отмечены юбилейные даты - такие, как 1925, 1955 и 1975 гг. ${ }^{2}$ Для советской историографии, по крайней мере, после 1920-х гг., было характерным значительное влияние идеологических установок. В течение десятилетий над советскими историками довлела необходимость следовать оценкам «Краткого курса истории ВКП(б)», тем более неизбежной на всем протяжении развития советской исторической была бесспорность ленинских оценок событий и итогов первой русской революции. Поэтому неудивительно, что значительный вклад в изучение различных вопросов был внесен зарубежными исследователями ${ }^{3}$ В В 1990-х гг. тема событий 1905-1907 гг., в особенности рабочего движения в это время, ушла на второй план как в российской, так и в зарубежной историографии ${ }^{4}$, но в последнее время, в особенности в связи со столетним юбилеем событий, интерес к этой теме начал возрождаться 5 .

1. В. Обнинский, Полгода русской революции: Сборник материалов к истории русской революиии (октябрь 1905 - апрель 1906 г2.), вып. 1, М., 1906.

2. См., например: 1905: Материаль и документы (под ред. М.Н. Покровского), М.-Л., 1925; 1905: История революционного движения в отдельных очерках (под ред. М.Н. Покровского), т. 1-3, М.-Л., 1925-1927; Революиия 1905 года: Материаль и документы (под ред. В.И. Невского), Харьков, 1925; Революция 1905-1907 годов (под ред. А.В. Федорова), Л., 1956; Революиия 1905-1907 годов в России: Документы и материалы, М.Л., 1955; Е. Д. Черменский, Буржуазия и изаризм в первой русской революции, М., 1970 Революция 1905-1907 годов. Документы и материалы, М., 1975; Революция 19051907 годов в России, М., 1975; Первая русская революция и ее историческое значение: Сборник документов и материалов, М., 1975; У.А. Шустер, Петербургские рабочие в 1905-1907 г2., Л., 1976; К.Ф. Шацилло, 1905-й год, М., 1980; Рабочий класс в Первой русской революции 1905-1907 г2., М., 1981; Н.Г. Королева, Первая российская революция и иаризм: Совет министров России в 1905-1907 г2., М., 1982; Л.Е. Шепелев, Царизм и буржуазия в 1904-1914 г2.: Проблемы торгово-промышленной политики, Л., 1987; Р.Ш. Ганелин, Российское самодержавие в 1905 году: Реформы и революция, СПб., 1991.

3. См., например: A. Ascher, The Revolution of 1905: Russia in Disarray, Stanford, 1985; Idem, The Revolution of 1905: Authority Restored, Stanford, 1992; L. Engelstein, Moscow, 1905: Working-Class Organization and Political Conflict, Stanford, 1982; V.E. Bonnell, Roots of Rebellion: Workers' Politics and Organizations in St. Petersburg and Moscow, 1900-1914, Berkeley, 1983; F.-X. Coquin, C.-P. Gervais-Francelle, éds., 1905: La première révolution russe, P., 1986.

4. Здесь можно отметить разве что сборник 1905 год - начало революционных потрясений в России ХХ века: Материаль международной конференции (М., 1996).

5. Специального внимания заслуживает коллективная монография Первая русская революция в России: взгляд через столетие (Отв. ред. А.П. Корелин, С.В. Тютюкин, M., 2005), а также сборник The Russian Revolution of 1905: Centenary Perspectives (Ed. by A. Heywood, J.D. Smele, London, 2005). 


\section{Рисунок 1}

Динамика числа рабочих, подавших жалобы на предпринимателей в фабричную инспекцию 1901-1912 гг. (в абсолютном и процентном количестве рабочих)

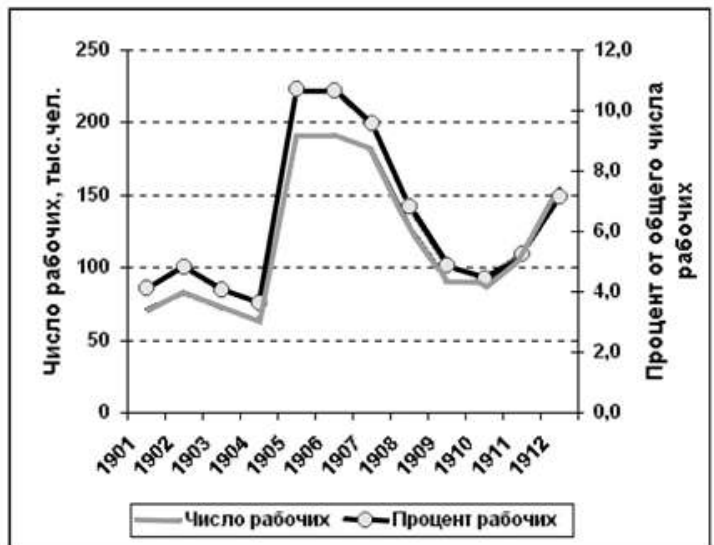

Источник данных: Свод отчетов фабричныхх инспекторов за 1912 г. СПб., 1913. C. LVI.

Однако следует отметить, что в работах по революции 1905-1907 гг., как правило, прямые вопросы о взаимоотношениях рабочих и хозяев предприятий часто оставались в тени. Даже если сосредоточиться только на исследованиях, рассматривающих сами события и их итоги с точки зрения изменения положения рабочих, мы почти всегда встречаем класс рабочих, противопоставленный классу эксплуататоров. В таком ракурсе обычно правительство не отличается от промышленников, и они выступают как нечто единое в своих (обыкновенно антирабочих) целях и методах. Если же в каких-то работах мы и находим противопоставление промышленников и предпринимателей правительству, то в контексте событий 1905-1907 гг. речь почти всегда ведется о либерализме, представительствах фабрикантов в различных политических партиях, но уже не о рабочем движении. Пожалуй, лучшим исключением здесь являются исследования В.Я. Лаверычева, в которых ставилась попытка рассмотреть взаимодействие сторон в треугольнике «правительство»«капиталисты» - «рабочие», но и у него акцент интересов смещен в сторону изучения возникновения и деятельности союзов и комитетов промышленников как антирабочих организаций

Между тем, перед администрацией каждого отдельно взятого завода или фабрики вставала самостоятельная задача, как договариваться со своими рабочими, чтобы они согласились работать, и независимо от организованности рабочего движения или союзов промышленников, даже независимо от разового вмешательства полиции или войск финальным и важнейшим результатом

6. В.Я. Лаверычев, По ту сторону баррикад: Из истории борьбы московской буржуазии с революцией, М., 1967; Он же, Царизм и рабочий вопрос в России: 1861-1917 г2., М., 1972. 
волнений и беспорядков на каждом конкретном предприятии становился новый договор, причем администрация, которой предстояло и дальше уживаться со своими рабочими в рамках нового договора, сама решала, насколько далеко в уступках рабочим она может и хочет зайти.

Исследование мотивов и финального поведения как рабочих, так и предпринимателей на этом уровне представляется возможным только с привлечением нового корпуса источников, позволяющих проводить микроанализ проблемы на материале конкретных предприятий. В данной статье делается попытка именно с этих новых позиций рассмотреть взаимные отношения между различными действующими лицами первой русской революции рабочими, промышленниками и правительством.

\section{Последствия 1905 года глазами предпринимателей}

В последнее десятилетие в исследованиях по рабочей истории стали широко применяться новые методики и подходы. В частности, основой нескольких крупных исторических исследований стало комплексное изучение делопроизводственной документации ряда крупных дореволюционных промышленных предприятий․․ Подобный микроанализ позволяет полно и притом взвешенно, на базе достаточно объективных документов, описать функционирование этих предприятий и рассмотреть динамику трудовых отношений, которые на них складывались.

Одним из объектов подобного рассмотрения стало товарищество мануфактур Н.Н. Коншина в Серпухове - одно из крупнейших текстильных предприятий Московской губернии. На четырех коншинских фабриках, выполнявших все операции по производству и отделке хлопчатобумажных тканей, трудилось к началу хх в. более 11 тысяч рабочих ${ }^{8}$. Вместе с тем, коншинские фабрики - это типичное крупное текстильное предприятие дореволюционной России; те же основания трудовых отношений прослеживаются и на многих других крупных фабриках.

Анализ делопроизводства показывает, что администрация коншинских фабрик делала для рабочих довольно много, причем в динамике положение рабочих заметно улучшалось практически по всем показателям с 1880-х годов

7. См., например: И.В. Поткина, На Олимпе делового успеха : Никольская мануфактура Морозовых, 1717-1917, М., 2004; А.М. Маркевич, А.К. Соколов, «Магнитка близ Садового кольиа»: Стимулы к работе на Московском заводе «Серп и молот», 1883-2001 г2., M., 2005.

8. Подробнее о товариществе мануфактур Н.Н. Коншина см. здесь: А.И. Аксенов, Ю.А. Петров, «Коншины-серпуховские», Предпринимательство и предприниматели России: От истоков до начала хх века, М., 1997, с. 201-215; Ч.М. Иоксимович, Мануфактурная промышленность в прошлом и настоящем, т. 1, М., 1915, с. 270-281. Трудовые отношения на этом предприятии подробно разбираются в выходящей в текущем году монографии: Л.И. Бородкин, Т.Я. Валетов, Ю.Б. Смирнова, И.В. Шильникова, «Не рублем единым»: Трудовые стимулы рабочих-текстильщиков дореволюционной России, М., 2008. 
и до самого 1914 года. Однако в период 1905-1907 годов рабочие добились наиболее впечатляющих уступок.

Коншинские фабрики бастовали неоднократно, но прямые результаты забастовок были обычно небольшими. Однако в октябре 1905 года состоялась трехнедельная забастовка, которая охватила рабочих сразу трех фабрик, - ситценабивной, прядильно-ткацкой и Новой ткацкой, - и стала крупнейшей из всех предыдущих. Уже в самом начале забастовки, 8 октября, правление товарищества, несомненно, видевшее размах стачечного движения по всей стране, пошло на значительные уступки рабочим. В частности, оно подняло размер квартирных выплат и увеличило плату за сверхурочные работы рабочим механического отделения (за них теперь обещано было платить в двойном размере против прежнего полуторного). Через неделю, 14 октября, «в настоящей заботе о нуждах своих рабочих и приняв во внимание их заявления о неправильностях в расценках», правление увеличило также и ставки заработной платы (в среднем расценки были повышены на $8 \%{ }^{9}$, однако индивидуально рабочие, согласно расчетным книгам, получили различные прибавки). Тем не менее, рабочие не вышли на работу, считая уступки недостаточными. Тогда правление после нескольких попыток наладить работу пошло на полный локаут, объявив о закрытии фабрик «на неопределенное время» и предложив всем рабочим расчет. После этого объявления, увидев, что большего добиться не удастся, рабочие прекратили забастовку (24 октября) ${ }^{10}$.

В дальнейшем в течение первой русской революции коншинские фабрики не принимали участия в стачечном движении, но для замирения фабрик правлению товарищества приходилось принимать всё новые постановления об улучшении положения рабочих. В своих объявлениях администрация, апеллируя к благоразумию рабочих, убеждала их, что и без давления со стороны рабочих делает и будет делать впредь все возможное для улучшения их положения. «В течение последнего смутного времени рабочие Товарищества Мануфактур Н.Н. Коншина, - говорилось, например, в одном из объявлений, - несмотря на забастовки рабочих на других фабриках, оставались всегда совершенно спокойными и с обычным усердием и добросовестностью производили свои работы. В этом Правление фабрики видело доверчивое отношение к нему рабочих и с своей стороны всегда заботилось об улучшениях жизни и быта их. Уже в начале текущего года был уменьшен рабочий день и повышена заработная плата; с тех пор разрабатывался вопрос о дальнейших улучшениях в этом направлении. Но в последнее время, когда в поведении рабочих Ситце-Набивной фабрики Правление увидело новое подтверждение их благоразумного, благонадежного и добросовестного отношения к общему делу, оно нашло возможным, ранее чем

9. Аксенов, Петров, «Коншины-серпуховские», с. 212.

10. ЦИАМ (Центральный исторический архив г. Москвы), ф. 673, оп. 1, д. 258, л. 9-12, $69,73,77,84$. Большая часть этих документов, прежде всего объявлений администрации рабочим, опубликованы: А.Ю. Володин, «Объявление как форма коммуникации фабричной администрации с рабочими (по материалам объявлений фабрик Товарищества мануфактур Н.Н.Коншина в октябре 1905 г.)», Экономическая история: Обозрение, вып. 8, M., 2002. 
предполагало, представить рабочим Ситце-Набивной фабрики новые льготы и тем показать им, что Правление умеет ценить и вознаграждать заслуги своих рабочих». Далее в объявлении приводились решения о сокращении рабочего дня и повышении заработной платы ${ }^{11}$.

Перечень уступок, на которые пошло правление уже 8 октября 1905 года, достаточно широк. Здесь встречаются распоряжения самого разного характера: «Женщины и дети не будут допускаться на перенос тяжестей», «Правление согласно на замену харчевой лавки - лавкой общества потребителей» или, наконец, «Рукомойники будут устроены в каждом отделении» ${ }^{12}$.

Рисунок 2

Динамика суммарной заработной платы на ткацких фабриках товарищества мануфактур Н.Н. Коншина, 1904-1907 гг.

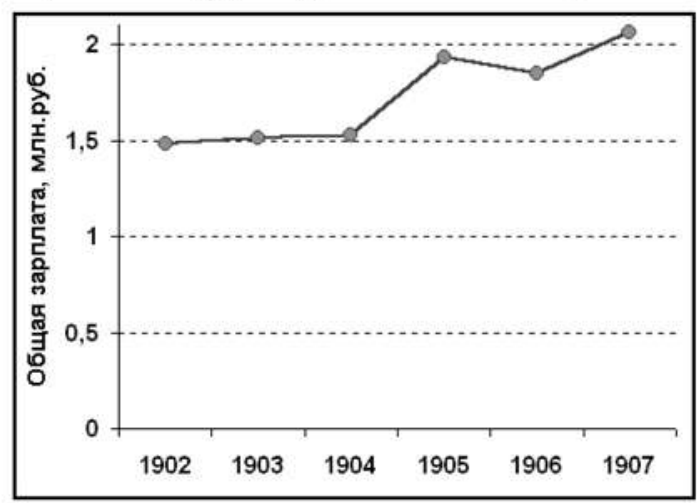

Источник данных: ЦИАМ. Ф.673. Оп.1. Д.358. Л.40об.

Наибольшие уступки, однако, были связаны с увеличением заработной платы и повышением квартирных денег. Так, хотя заработная плата рабочих постоянно росла в течение всего периода с конца 1870-х годов, только в 1905 г., впервые за весь период существования товарищества, ставки заработной платы были подняты всем рабочим сразу, как квалифицированным, так и неквалифицированным. Общая сумма заработка рабочих двух ткацких фабрик (примерно 8 тысяч человек) в 1902-1904 гг. составляла около 1,5 млн. рублей в год, в 1905-1907 гг. - уже около 1,9 млн. рублей в год (см. рис. 2). Напротив, штрафы существенно сократились. Штрафы на коншинских фабриках не составляли значительных сумм даже и до принятия закона 1886 г., запрещавшего возврат штрафных сумм в прибыль, и в 1902-1904 гг. общая сумма штрафов составляла лишь $0,12-0,16 \%$ от общей суммы заработка, но после 1905 г. и эта сумма сократилась вдвое. При этом размер пособий, выдаваемых рабочим из штрафного капитала, также сократился, но не столь заметно. И в 1904 г.

11. ЦИАМ, ф. 673 , оп. 1, д. 201, л. 99.

12. Там же, д. 258, л. 9-12. 
администрация платила пособия рабочим в большем размере, чем позволял штрафной капитал, но с 1905 г. размер этих выплат увеличился (см. рис. 3).

\section{Рисунок 3}

Динамика общих сумм штрафов и пособий на всех фабриках товарищества мануфактур Н.Н. Коншина, 1904-1910 гг.

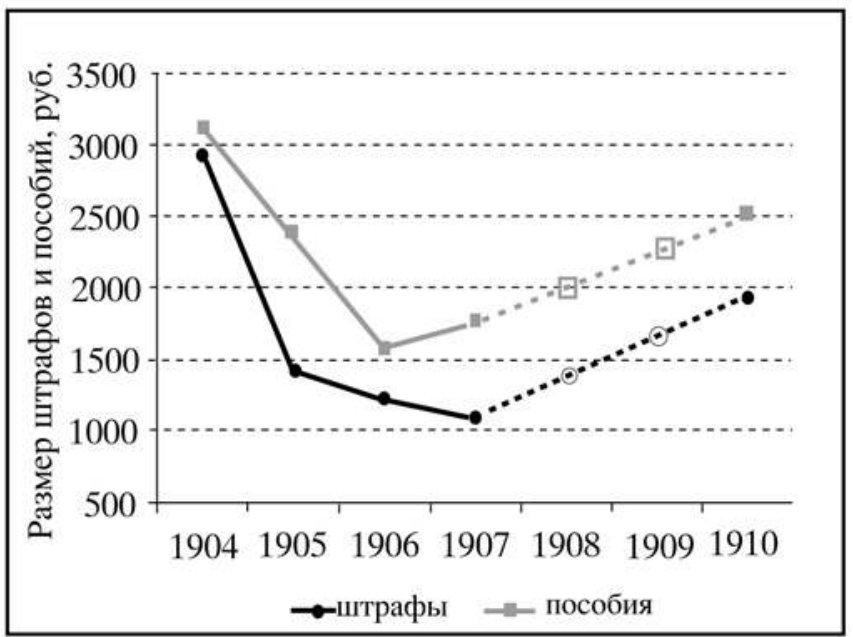

Пунктиром условно восстановлены данные за те годы, по которым не имеется сведений

Источник данных: ЦИАМ, ф. 673 , оп. 1 , д. 202 , л. 108 ; д. 259 , л. 47 ; д. 259 , л. 183 ; д. 438, л. 133 ; д. 601, л. 135.

Интересно отметить, что такое же положение выявляется и на других крупных предприятиях, для которых проведена работа по сбору соответствующих данных. Так, фактически тот же провал в капитале штрафных сумм в 1905-1907 гг. характерен и для Московского Металлического завода Ю.П. Гужона, - это при том, что как условия работ, так и позиция хозяина завода относительно отношений с рабочими, там были принципиально другими (см. рис. 4). 


\section{Рисунок 4 \\ Динамика общих сумм штрафов на Московском Металлическом (Гужоновском) заводе, 1901-1910 гг.}

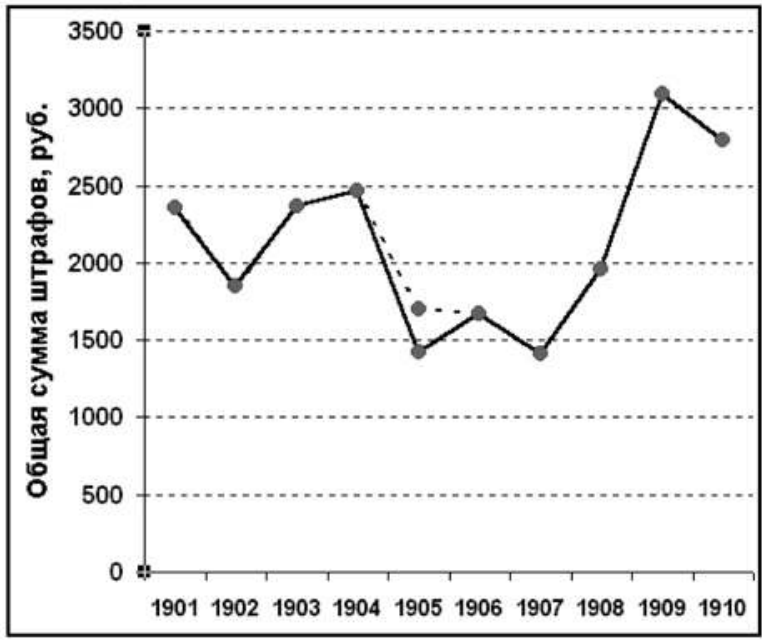

Пунктиром показано нормализованное значение, учитывающее, что в 1905 r. почти два месяца завод стоял и, соответственно, штрафы взимались только 10 месяцев.

Источник данных: А.М. Маркевич, А.К. Соколов, «Магнитка близ Садового кольца»: Стимульы к работе на Московском заводе «Серп и молот», 1883-2001 г2. М., 2005. С. 46.

Другим важным моментом взаимоотношений рабочих и администрации было предоставление рабочим жилья. Примерно две трети коншинских рабочих были обеспечены местами в фабричных казармах; для этого к 1905 г. было выстроено 28 корпусов, но всем жилья все равно не хватало, и многие получали «квартирные деньги» - на наем квартир. Размер выплат - 1 рубль в месяц - был недостаточным даже для того, чтобы снять приличный угол, и коншинские рабочие (как и многие другие) часто требовали повышения квартирной выплаты. Увеличение этой выплаты до 1,5 рублей в месяц в 1905 г. повлекло серьезные расходы для администрации (см. рис. 5 и 6).

Из рис. 5 видно, что рост трат администрации на жилье рабочих опережал рост числа рабочих, однако это расхождение между двумя представленными динамиками приходится в основном на 1905-1906 гг., причем рис. 6 совершенно определенно показывает, что качественные изменения связаны преимущественно с ростом объема квартирных выплат. В 1906 г. выплаты квартирных денег возрастают по сравнению с 1904 г. почти в три раза.

Итак, микроанализ истории предприятия показывает, что в 1905-1907 гг. администрацией коншинских фабрик были сделаны серьезные увеличения расходов в пользу рабочих, и важно, что та же ситуация характерна и для многих других крупных фабрик. 
Рисунки 5-6

Динамика трат на жилье рабочих товарищества мануфактур Н.Н. Коншина, 1902-1907 гг.
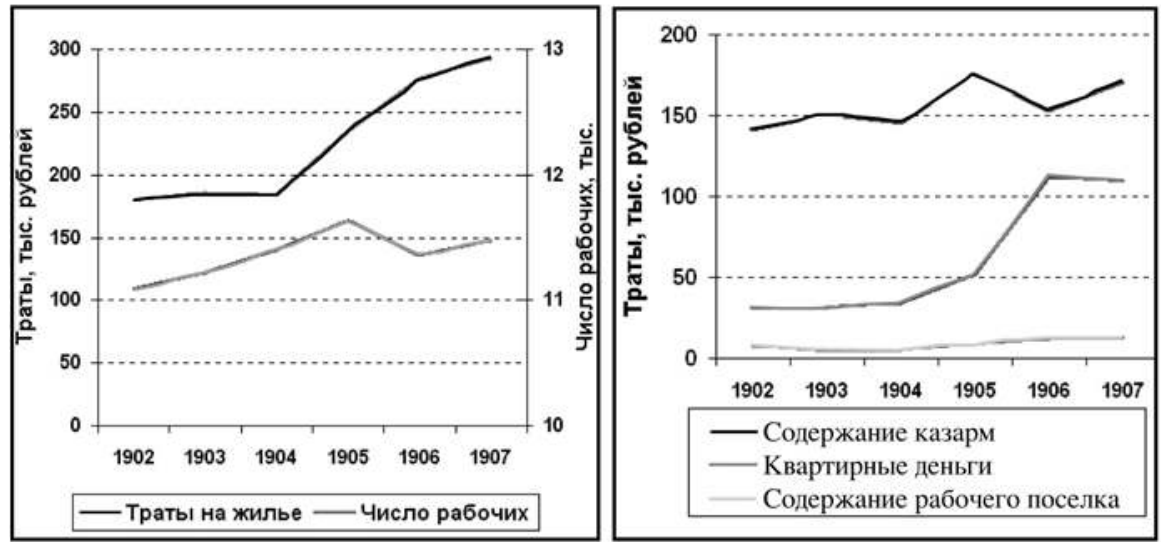

Источник данных: ЦИАМ. Ф.673. Оп.1. Д.358. Л.45об.

\section{Последствия 1905 года глазами рабочих}

Однако полученные уступки совершенно не воспринимались рабочими как повод к прекращению требований. Действительно, еще с 1880-х годов из года в год происходило увеличение зарплаты (при фактическом отсутствии инфляции), сокращался рабочий день, улучшались жилищные условия рабочих и обеспечение их медицинской помощью и т.д. Но это улучшение началось с такого низкого уровня, что и к 1905 году нельзя было говорить о человеческих условиях труда и жизни большинства рабочих, особенно в ряде таких отраслей, как текстильная, где рабочий день все равно составлял 10-11 часов, а зарплата была небольшой. Положение рабочих медленно улучшалось, но значительно быстрее распространялось осознание ими собственной приниженности и несправедливости этого положения. Если в результате борьбы удалось добиться такого же увеличения выплат со стороны администрации, какое до этого нужно было ждать десять лет, - то это было хорошим поводом к тому, чтобы продолжать борьбу и дальше.

К тому же 1905 год показал примеры успешной реализации идей и практики социалистической партийной борьбы. Ранее, в хІХ веке, стачки носили по преимуществу экономический и локальный характер - рабочие требовали улучшения только собственного положения. Постепенно в требования бастующих начали включаться и политические лозунги - рабочие стали понимать, что вся система не даст им добиться значительных перемен к лучшему. Однако главное место по-прежнему занимают экономические 
требования. В 1905 г. в стачечном движении очень ярко, как никогда раньше, проявляется и рабочая солидарность - сразу на многих предприятиях выдвигаются одни и те же лозунги, зачастую очевидно неприемлемые, вроде требования предоставления рабочим права назначать и смещать мастеров и служащих или требования введения 8-часового рабочего дня, что никак не могло бы быть выполнено без соответствующего законодательного решения ${ }^{13}$.

Несомненно, подобная рабочая солидарность была организованной. Изза этого возникали и анекдотические ситуации. Так, общая волна стачек захватила и Никольскую мануфактуру Морозовых, предприятие, на котором положение рабочих значительно превосходило средний уровень, даже если принимать во внимание только крупные фабрики. Рабочие предъявили свои требования из 95 пунктов, через две недели администрация дала свой ответ. Некоторые требования были отвергнуты, другие было обещано реализовать, но интересно, что в 18 случаях фактическим ответом было «Так уже делается». Очевидно, что правлению фабрики были выставлены «типовые» требования, разработанные без учета практики, принятой на этом конкретном предприятии ${ }^{14}$.

Первая русская революция привела к значительным результатам, и многие рабочие увидели и осознали, что за свои требования можно результативно бороться, что социалистические организации правы, а фабриканты слабы, и что хаос и беспорядки дают больше, чем дисциплина и добрая воля администрации. В дальнейшем рабочие уже часто предпочитали именно боевой тон в разговорах с администрацией. Один из высших служащих коншинской ткацкой фабрики писал в докладной записке в правление товарищества в 1909 году:

Я считаю необходимым обратить внимание Правления на крайне возбужденное и зачастую вызывающее настроение рабочих. Мельчайший факт случайно оказанного им невнимания служит источником возбуждения. В каждый данный момент нельзя поручиться, что они не явятся с каким-нибудь требованием или претензией <...> Браковщики напуганы воинственным тоном ткачей, многие куски откладывают до резолюции мастера. По их указаниям брак значительно увеличился, а такие невинные вещи, как требование вычистить кусок, вызывают со стороны ткачей резкие протесты, мотивируемые тем, что в красильном отделении все невычищенные концы на палильных машинах исчезнут и, стало быть, это только придирка, каковую исполнять они не намерены.

13. В исследовательской литературе о стачечном движении в 1905-1907 гг. было наглядно показано, что хотя главные требования бастующих рабочих значительно чаще были связаны с увеличением заработной платы, чем с уменьшением рабочего дня, именно в 1905-1907 гг. требования сокращения рабочего времени появляются в большом количестве, причем рабочим удалось добиться в этом направлении существенных успехов. Разумеется, распространенное в эти годы требование введения 8-часового рабочего дня, которое было чисто политическим требованием, не могло быть удовлетворено, но сокращение рабочего дня на час-полтора без снижения дневной заработной платы было достигнуто на множестве фабрик и заводов. См., например: Ю.И. Кирьянов, Жизненный уровень рабочих России: конеи хІх-начало хх в., М., 1979, с. 54-55.

14. Поткина, На Олимпе делового успеха..., с. 358-371. 
Близны, неразработанные подплетины и недосеки они объясняют исключительно дурной пряжей, но не небрежностью своей работы, словом, они считают себя хозяевами положения.

Я твердо уверен, что в недалеком будущем не миновать осложнений, ибо тон их повышается с каждым днем, а меры к уменьшению брака придется принимать более решительные, чем это практиковалось до сих пор.

Молодежь в казармах ведет себя вызывающе, и сторожа, а также и городовые, боятся их угроз. Пьянство процветает в полной мере.

Везде, при каждом требовании лучшей или интенсивной работы, наталкиваешься если не на явный протест, то на скрытую оппозицию, при жалобах на судьбу и несчастное положение рабочего человека. В стремлении директора и его помощников привести работу хоть в маломальский порядок, урегулировать отношения между рабочими и выше их стоящими, доказать, что работа в данных условиях невозможна, ибо постоянная травля администрации, эпидемические крючкотворство и придирки создают положение одинаково невыгодное как рабочим, так и предпринимателям, должно находить твердую поддержку в Правлении, ибо без этого рабочие останутся при своем заблуждении, что по их требованию могут быть смещены неугодные для них служащие. Социалдемократическая пропаганда настолько возбудила аппетиты, теория борьбы классов настолько подогрела ненависть и недоверие, что всякое требование сносной, добросовестной работы понимается как грубая эксплуатация и посягательства на права пролетариата. ${ }^{15}$

Такое же наблюдение, только распространенное на всех промышленных рабочих вообще, высказал профессор И.И. Янжул, который сам хорошо знал положение рабочих и сделал очень многое для привлечения общественного мнения к «рабочему вопросу». В самом начале своих воспоминаний, вышедших в 1907 г., он написал: «Насколько наш рабочий был недавно бесправен и безличен и в общественном мнении принижен и забит, настолько он теперь ложно чересчур возвеличен и в общественном мнении, и, что опасно, в своем собственном» 16 .

С одной стороны, рост самосознания рабочих, перешедший после 1905 года на качественно новый уровень, имел свои положительные стороны, потому что рабочие уже не ждали доброй воли хозяина и лучше понимали собственное положение. С другой стороны, слишком резкое усиление рабочего самосознания, прошедшее через революционную закалку, сделало почти невозможным путь мирных переговоров для дальнейшей эволюции трудовых отношений.

15. ЦИАМ, ф. 673, оп. 8, д. 6, л. 380-385.

16. И.И. Янжул, Из воспоминаний и переписки фабричного инспектора первого призыва: Материалы для истории русского рабочего вопроса и фабричного законодательства, СПб., 1907, с. 5. 


\section{Последствия 1905 года глазами правительства}

Наконец, интересно взглянуть, как же отреагировало правительство на революционное обострение «рабочего вопроса». Главный политический итог первой русской революции для российской короны известен - это принятие Манифеста 17 октября ипоследующая утомительная борьба с Государственной Думой. Однако нам важно не это. Интересно узнать другое - что сделало правительство для того, чтобы сгладить напряженность в отношениях рабочих и фабрикантов там, где последние сами не пошли на уступки?

Конечно, правительство должно было бы предпринять какие-то меры в этой области, в первую очередь, посредством издания новых законодательных актов. В крестьянском вопросе так и было сделано - манифестом 3 ноября 1905 г. была наконец (более чем через 40 лет после отмены крепостной зависимости) провозглашена отмена выкупных платежей. О социальной и экономической значимости этого решения можно спорить, но соответствующий закон определенно свидетельствует, что оно было сделано именно для смягчения напряженности в деревне - в текст закона были даже введены отеческие наставления о вреде беспорядков вроде следующих: «Насилия и преступления не улучшают положения крестьян, а Родине они могут принести много великого горя и бед» ${ }^{17}$.

Было бы вполне естественно ожидать чего-либо подобного и в рабочем вопросе. Однако изучение фабричного законодательства показывает, что за весь промежуток 1905-1907 гг. для улучшения положения рабочих реально было сделано совсем немного. Приведем полный список законодательных актов, касающихся рабочего вопроса и изданных в это время:

- 6 июня 1905 (№ 26357) - О вознаграждении потерпевших вследствие несчастных случаев и повреждений в здоровье мастеровых, рабочих и вольнонаемных служащих в предприятиях фабрично-заводской, горной и горнозаводской промышленности ведомства Кабинета Е.И.В. и Уделов;

• 2 декабря 1905 (№ 26987) - О временных правилах о наказуемости участия в забастовках в предприятиях, имеющих общественное или государственное значение, а равно в учреждениях правительственных, и об обеспечении судьбы тех служащих, кои, не принимая участия в забастовках, пострадали от учиненного над ними насилия;

• 19 декабря 1905 (№ 27072) - О вознаграждении потерпевших вследствие несчастных случаев... в Государственной Типографии;

10 февраля 1906 (№ 27385) - О вольнонаемных мастеровых и рабочих технических артиллерийских заведений;

6 марта 1906 (№ 27485) - О вознаграждении потерпевших вследствие несчастных случаев... в Сенатской Типографии;

17. «Об уменьшении и последующем прекращении выкупных платежей с крестьян бывших помещичьих, государственных и удельных», Полное собрание законов Российской империи, Собрание третье, т. XXV, № 26872. 
- 6 марта 1906 (№ 27490) - О вознаграждении потерпевших вследствие несчастных случаев... рабочих морского ведомства;

- 19 апреля 1906 (№ 27737) - О вознаграждении потерпевших вследствие несчастных случаев... в состоящих в ведении торговых портов казенных предприятиях.

Фактически, за исключением закона об ответственности за стачки, правительство пошло только на распространение на рабочих ряда государственных предприятий закона 2 июня 1903 г. по страхованию от несчастных случаев на производстве, а для рабочих частновладельческих предприятий не сделало ничего. Более того, и позднее, вплоть до 1912 г., фабричное законодательство не пополнилось новыми статьями.

Впрочем, экстренные действия в направлении принятия новых законов для рабочих как раз были предприняты. Инициатором их стал новый министр финансов В.Н. Коковцов, который, впрочем, видимо, взял за основу идеи, подготовленные С.Ю. Витте. Уже 11 января 1905 г. Коковцов обратился к императору с предложением мероприятий, направленных на усиление рабочего законодательства. Важнейшим пунктом здесь было предложение законодательного сокращения рабочего времени в промышленности до 10 часов в день (вместо существующих по закону 1897 г. 11,5 часов); также предлагались меры по государственному страхованию рабочих, регулированию предоставления им врачебной помощи и существенное смягчение наказаний за участие в стачках. Николай II, в общем, одобрил предложенную программу, и дело пошло обычным для принятия «проблемных» законов бюрократическим чередом. Очень неспешно создалась комиссия, для работы в которой были также приглашены некоторые крупные промышленники, но, естественно, в которой не могло и быть делегатов от рабочих.

Деятельность так называемой комиссии Коковцова была хорошо проанализирована Б.А. Романовым, который издал и ряд основных материалов, посвященных ее работе ${ }^{18}$. Принципиально важные слушания в этой комиссии состоялись только в мае, и здесь сразу обнаружилось явное нежелание промышленников идти на усиление рабочего законодательства. Министр финансов в январе, объясняя недостаточность имеющихся в законе мер, писал: «Последствием задержки в развитии нашего фабрично-заводского законодательства было то, что рабочее наше движение, не будучи удерживаемо в течении своем определенными рамками положительного закона, уклонилось с свойственного ему пути чисто экономического характера и попало под влияние политической агитации $<\ldots .>$ Революционное брожение $<\ldots>$ могло быть если не совсем устранено, то в достаточной мере ослаблено своевременною регламентациею наиболее обострившихся вопросов». Напротив, предприниматели заявляли в мае: «Деятельность настоящей комиссии вызвана не естес-

18. Рабочий вопрос в комиссии В.Н. Коковцова в 1905 г, М., 1926, сост. Б.А. Романов. На английском языке существует значительно сокращенное описание работы этой комиссии: G.E. Snow, «The Kokovtsov Commission: An Abortive Attempt at Labor Reform in Russia in 1905», Slavic Review, 31(4), 1972, p. 780-796. 
твенным течением промышленной жизни, а происходившими в последнее время и продолжающимися еще ныне в разных концах России массовыми забастовками рабочих». Логическим продолжением сказанного было следующее: «Каждый из названных четырех законопроектов не вытекает из постепенно нарастающих потребностей промышленной жизни, не является необходимым моментом планомерного развития средств к поднятию благосостояния рабочих (к чему могли бы служить и иные, более верные пути)». В итоге промышленники добились того, что деятельность комиссии была отложена на неопределенное время, после чего так и не собралась больше. «Мы думаем, что откладывая эту комиссию, мы ровно ничего не упустим, - говорилось в их заявлении. - Если то громадное бедствие, которое постигло Россию [поражение под Цусимой], не успокоит и не образумит наших рабочих, которые и в настоящее время продолжают свои смуты, то во всяком случае не те законы, которые мы вырабатываем и придумываем, будут в состоянии их успокоить.» ${ }^{19}$

Поведение предпринимателей, проваливших принятие новых рабочих законов, можно объяснять простым нежеланием нести дополнительные убытки от введения новых мер в пользу рабочих, также как и боязнью, что уступки, ставшие результатом забастовок, вызовут лишь новые требования. Однако это может быть лишь частью объяснения, потому что, как показано выше, на уровне собственного предприятия те же самые промышленники готовы были идти на уступки рабочим, - среди привлеченных к работе в комиссии Коковцова были и владелец Московского Металлического завода Ю.П. Гужон, и директор правления товарищества мануфактур Коншина В.С. Баршев ${ }^{20}$. Следовательно, можно предположить, что еще важнее предпринимателям было не поступиться своими правами на то, чтобы самим решать меру уступок рабочим, на которые они бы могли пойти. Хозяин фабрики сам хотел быть «отцом рабочих» и не готов был передать это право министру финансов или, вообще говоря, царю. И хотя на конкретной фабрике у каждого члена комиссии в этом был, конечно, определенный резон, в целом выборные от предпринимателей в очередной раз сорвали принятие перезревших мер, которое, возможно, и могло бы в определенной мере сгладить социальные противоречия в обществе.

А министр финансов, со своей стороны, столкнувшись с противодействием промышленников, не смог провести в жизнь свои предложения. Очевидно, что не одна только позиция предпринимателей сыграла тут свою роль. Наверняка можно предполагать здесь и влияние министерства внутренних дел, которое традиционно имело свой оригинальный взгляд на остроту «рабочего вопроса» и способы его разрешения, и противодействие консервативных сил, полагающих невозможным само выставление требований со стороны рабочих, и отсутствие достаточной решительности со стороны сторонников дальнейшего расширения рабочего законодательства. Представляется совершено спра-

19. Рабочий вопрос в комиссии В.Н. Коковцова.., с. 22, 202, 54, 236.

20. Там же, с. 37. 
ведливым комментарий Б.А. Романова: «Для проведения в жизнь этой программы в тогдашних условиях требовалась особенная и гибкость, и быстрота действия, что было, однако, не под силу старому аппарату» ${ }^{21}$. А в итоге для рабочих вся деятельность комиссии Коковцова закончилась ничем и прошла незаметно, то есть как будто бы правительство самоустранилось от решения проблем, имеющих жизненно важное значение для рабочих.

\section{Общие итоги}

В литературе часто можно встретить тезис о том, что в России на протяжении всей истории чрезмерно велика историческая роль государства. Всякие инициативы - хорошие или плохие - по большей части исходили от государства. Правительство проводило крупные реформы, к которым еще не было готово общество, и само же правительство мелочно регулировало каждый шаг этого недоразвитого общества. Государство заставило открывать заводы и тем самым создало промышленность в XVII веке. В ХІх и начале хх вв. от государственных заказов часто зависели судьбы крупнейших промышленных предприятий. Уставы каждого акционерного общества визировались государем императором лично, в результате чего принимали статус общероссийских законов и публиковались в Полном собрании законов Российской империи.

Государство шло впереди многих предпринимателей и в области регулирования трудовых отношений. На собственных заводах и предприятиях различные министерства вводили щадящие правила внутреннего распорядка еще в 1860-х-1870-х годах, когда в частной промышленности были повсеместно распространены совершенно невозможные условия труда. Неоднократно появлялись комиссии по разработке фабричного законодательства, проекты которых терпели крах под натиском предпринимателей, однако в 1880-х годах наконец вступили в силу законы, охранявшие рабочих частных фабрик и заводов в самых принципиальных вопросах. Правда, на финальной стадии почти все проекты фабричных законов претерпевали изменения в пользу фабрикантов и потому часто получались не очень актуальными. Скажем, законодательное ограничение продолжительности рабочего дня до 11,5 часов, принятое в 1897 г., на большинстве предприятий отставало от принятой в производстве практики, но все же государство изданием законов задавало общий тон в трудовых отношениях.

Но к началу хх века предприниматели, особенно владельцы крупных фабрик и заводов, стали вводить у себя правила, существенно опережающие фабричное законодательство, и 1905 год выявил это с особенной отчетливостью. Вся страна была охвачена недовольством, рабочие повсеместно выдвигали хозяевам фабрик и заводов политические требования, и крупные промышленники зачастую смягчали условия труда на своих предприятиях,

21. Там же, c. VI. 
а вот правительство уже не смогло принять никаких существенных мер для решения всех этих проблем.

Через десять дней после расстрела демонстрации 9 января 1905 года к императору Николаю II были доставлены делегаты от рабочих, перед которыми он произнес речь. Завершая речь, государь заявил им, что прощает их ${ }^{22}$. Подобное заявление вполне естественно для самодержца великой империи, однако таким образом высказать его мог только человек, плохо понимающий реальную ситуацию. Не прошло и года, как великая империя разразилась настоящей революцией, и все извлекли какие-то уроки для себя, но уроки оказались разными, и согласие стало еще менее возможным.

Московский государственный университет

Исторический факультет

tim@hist.msu.ru

22. Подробнее об этом эпизоде см.: Первая русская революиия в России: взгляд через столетие, с. 184-185 и Лаверычев, Царизм и рабочий вопрос..., с. 190. 